Article

\title{
Anthropogenic Factors Control the Distribution of a Southern Conifer Phytophthora Disease in a Peri-Urban Area of Northern Patagonia, Argentina
}

\author{
Guillermo Giordana ${ }^{1}$, Thomas Kitzberger ${ }^{2}(1)$ and Ludmila La Manna ${ }^{3, *}$ \\ 1 Dirección de Evaluación Ambiental, Secretaría de Ambiente y Desarrollo Urbano, Municipalidad de San \\ Carlos de Bariloche, Ángel Gallardo 1301, Río Negro 8400, Argentina; g_giordana@hotmail.com \\ 2 Laboratorio Ecotono, INIBIOMA, CONICET-Universidad Nacional del Comahue, Quintral 1250, Bariloche, \\ Río Negro 8400, Argentina; kitzberger@comahue-conicet.gob.ar \\ 3 Centro de Estudios Ambientales Integrados, Facultad de Ingeniería, Universidad Nacional de la Patagonia \\ San Juan Bosco (UNPSJB)-Consejo Nacional de Investigaciones Científicas y Técnicas (CONICET), \\ Ruta 259 Km 16.4, Esquel, Chubut 9200, Argentina \\ * Correspondence: llamanna@unpata.edu.ar
}

Received: 19 September 2020; Accepted: 6 November 2020; Published: 9 November 2020

\begin{abstract}
Several mid-sized urban areas have established boundaries overlapping with the distribution of Austrocedrus chilensis (D.Don) Pic.Serm. \& Bizzarri forests in Patagonia. These forests suffer a disease whose primary cause is the aggressive pathogen Phytophthora austrocedri. This study analyzes the factors related to Austrocedrus disease in an urban and peri-urban environment, showing that anthropogenic factors related to Phytophthora dispersion predominantly influence the disease distribution. The study was developed in urban and suburban areas of San Carlos de Bariloche county (Río Negro Province, Argentina). A database of requests to fell A. chilensis trees, from the Forest Department of Río Negro Province, was cleaned up and improved through satellite images analysis and field sampling. Data were analyzed in order to set up a layer of Austrocedrus disease presence. From this layer, and from anthropogenic and environmental layers (distance to houses, distance to roads, precipitation, slope, aspect, altitude, distance to water courses), a risk model was developed using the Maximum Entropy (MaxEnt) algorithm. In turn, data from the field sampling were assessed by contingency tables and chi square analysis. The results show that disease occurrence in San Carlos de Bariloche county is associated with the insertion of the urban network over areas of native forests. Distance to houses, distance to roads and distance to gardens with irrigation were the most important variables associated with the disease occurrence. A risk model was generated for the study area, which shows the current risk situation for the disease. Urbanization's advance over the forest modifies key variables related to Phytophthora dispersion, such as the distance from cypress trees to houses and roads, thus progressively increasing the area at risk of becoming diseased. Based on these results, plausible measures and actions are proposed.
\end{abstract}

Keywords: mal del ciprés; soilborne pathogen; Austrocedrus chilensis; Phytophthora austrocedri

\section{Introduction}

The factors involved in the periodic occurrence of loss of tree vigour, branch dieback and tree mortality, a global phenomenon called forest decline, has become a major research objective among foresters, ecologists and plant pathologists. However, because of the complex interaction between host, site, climate and one or more pathogens, it is often difficult to unravel slow predisposing conditions (generally abiotic, e.g., soil, climate), from inciting short-term stress factors (e.g., drought, waterlogging, insect defoliations, etc.) and from contributing agents that weaken and ultimately kill 
trees (fungi, boring insects, etc.) [1]. Most of the world's forests have been influenced to some degree or other by human activity. These influences have had far reaching effects on ecosystem stability and dynamics and have been associated with many cases of forest decline. Anthropogenic factors of forest decline range from depositions of atmospheric pollutants (e.g., ozone, sulfur dioxide, etc.), introduction of pests (forest insects, fungi, etc.), fire exclusion (cohort senescence), hydrologic changes (altered salinity, waterlogging) to climate change (anomalous heat waves, drought events) [2]. In this sense, silviculture and forest management may play a key role in the control of these impacts [3,4].

With global trends of urbanization, many native forest landscapes are being rapidly transformed into peri-urban areas, often displaying rapidly developing tree decline syndromes. Suburban areas display increased air, water and soil pollution levels, and strong alteration of hydrological regimes due to sewage, irrigation, soil movements, channelization, artificial water body creation, diversion of streams, etc. In addition, the high levels of transit in these areas have the potential to further promote the dispersal of soilborne tree pathogens. All these changes have the potential to amplify the chances of producing tree decline syndromes in such landscapes. Despite this, there are relatively few studies that have analyzed the factors involved in tree decline in peri-urban area [5,6].

Austrocedrus chilensis (D. Don) Pic. Serm. \& Bizarri (ciprés), a southern South American conifer thriving in ecotone areas between the wet Nothofagus forests and the Patagonian steppe, suffers from a disease locally known as "mal del ciprés". Although "mal del ciprés" (Austrocedrus disease) was originally interpreted as a decline disease, with poorly drained soils as predisposing factor $[7,8]$, later studies showed that the primary cause of $A$. chilensis forests mortality is the aggressive pathogen Phytophthora austrocedri Gresl. \& E.M. Hansen [9]. Evidence indicates that P. austrocedri is, most likely, an exotic pathogen that was introduced to the Patagonian Andes in the early 1940s [10]. A. chilensis is its only known host in Patagonia, but the susceptibility of other native tree species from Cupressaceae has been demonstrated in vitro [11]. Host shift is recurrent in the case of Phytophthoras, as occurred for example with Phytophthora ramorum, which can infect more than one hundred species, including both U.S.-native forest and ornamental species [12].

The main symptoms of $P$. austrocedri infection are defoliation, necrotic lesions in the inner bark, and resin exudates. P. austrocedri penetrates the plant through the roots, and necrotic lesions extend from the killed roots to the tree bole, affecting the phloem and, superficially, the sapwood. Resin exudations usually emerge from a resin pocket in the phloem, near the active margin of a necrotic lesion [9]. Defoliation, even though is an unspecific symptom [13], is widely considered for assessing A. chilensis sanitary condition [14], and can be associated with the severity of $P$. austrocedri infection, since defoliation is related to the amount of root affected [9]. External symptoms are the results of the extensive death of bark and cambium tissues and the disruption of phloem transport, as well as by the blockage of xylem transport by hyphal colonization of parenchyma rays and tracheids [15]. Thus, P. austrocedri infection causes physiological [15] and anatomical changes in the tree [16]. Moreover, root death weakens the tree and allows the entrance of secondary biotic agents. In the sapwood of the main roots, and root collar, wood rot develops, caused by the Aphyllophorales fungi Postia dissecta (Lév) Rajchenberg and Coniophora arida (Fr.) Karst. [17]. These opportunist fungi produce root and sapwood rots, affecting the stability of the trees.

Several mid-sized urban areas, such as San Carlos de Bariloche, have been established along this sharp climatic/vegetation transition (ecotone), largely overlapping the distribution of $A$. chilensis with important ecological impacts on these forest ecosystems [18]. During the last few decades, considerable population growth (8.4-21.3\% increase from 1991 to 2001) and rapid urbanization (79.9-84.4\% urban population from 1991 to 2001) have occurred in Northern Patagonia (INDEC, National Institute of Statistics and Censuses of Argentina; http://www.indec.gob.ar). This rapid trend in urbanization and suburbanization in native forested areas bordering Nahuel Huapi National Park has made San Carlos de Bariloche (hereafter, Bariloche) the currently most populated (about 135,000 inhabitants) city in Andean Patagonia and the largest county in Argentina (ca. 22,652 ha) (http://www.saij.gob.ar/LPR2002614). This fast urban growth, fueled partially by the tourism industry, has generated increasing forest-society 
conflicts, such as wildland-urban interface fire risks [19], domestic animal-wildlife conflicts [20] and emerging public risks related to forest decline-induced treefalls [21,22].

Considerable progress has been made in identifying abiotic factors that predispose forest stands to suffer Austrocedrus disease along its natural range. Several site conditions play a key role in the development of Austrocedrus disease. Studies at different scales have found that the disease's occurrence is related to high rainfall, low to medium altitudes, gentle to moderate slopes and poorly drained soils $[7,8,23,24]$. Low slopes, nearness to water courses, to affected tress, to roads and trails are key factors that promote disease occurrence and spread risk in non-urban areas $[25,26]$. Studies at stand scale indicate that forests with the highest risks of disease are associated with wet soils, a factor that has been found to promote spread of several Phytophthora species [27]. P. austrocedri is a fungal-like pathogen whose spread is boosted by the abundance of rainfalls, flowing water, and waterlogged soils [28]. Even outside Patagonia, P. austrocedri has been found to affect Juniperus communis s.l in UK forests in waterlogged soil conditions [29].

It would be expected that climatic, topographic, and edaphic determinant factors for Austrocedrus disease distribution in natural areas lose relevance in the urban context, because P. austrocedri could be favored by the artificial wet associated with urbanization. For example, garden irrigation, home sewage septic systems, street damming of drainages and creeks and waterproofing of surfaces are known to largely alter soil moisture regimes in suburban areas. At the same time, an expanded and road/path network with increased automobile and human traffic could be favoring the spread of spores in the wheels or the footwear [30]. Thus, anthropization in the suburban environment could be amplifying pathogen spread and tree disease risks compared to the more natural surrounding landscape [29].

Since abiotic and anthropogenic factors could be highly related to disease distribution, the habitat association approach can be used to generate risk maps, an important tool for developing forest management criteria [31,32]. One of the most useful techniques to generate risk models is the MaxEnt algorithm (maximum entropy species distribution modelling). MaxEnt is a method based on presence data, that has been applied as well for modelling species potential distribution [33-35] and for modelling forest disease risk [25].

This study aimed to analyze the factors related to Austrocedrus disease in an urban and peri-urban environment and to develop a risk model, hypothesizing that anthropogenic factors related to Phytophthora dispersion mainly influence the disease distribution.

\section{Materials and Methods}

\subsection{Study Species and Study Area}

The subantarctic forests are located in the southwest of Argentina, between $35^{\circ}$ and $54^{\circ}$ south latitude, lying on the east side of the Patagonian Andes [36]. These forests are rich in endemic species, such as $A$. chilensis. The entire range of this conifer develops in a wide annual precipitation range, from 600 to $2000 \mathrm{~mm}$, and different types of soils [37,38].

The study area included the western portion of the urban and peri-urban areas of San Carlos de Bariloche county, Rio Negro province (Argentina), overlapping A. chilensis forests (Figure 1). The study area covers 8293 ha, distributed in pure $A$. chilensis or associated with lower trees/shrub species ( $2830 \mathrm{ha}$ ) and A. chilensis associated with coihue (Nothofagus dombeyi Mirb. Oerst.), a tall evergreen angiosperm tree dominating southern Andean forests at mid latitudes (5463 ha). The study area includes a high environmental gradient. Altitude ranges from 750 to $1800 \mathrm{~m}$. a.s.l., slope ranges from $0^{\circ}$ to $65^{\circ}$, with variable aspects, and mean annual precipitation ranges from 1300 to $2200 \mathrm{~mm}$ (Supplementary Material Figure S1). 


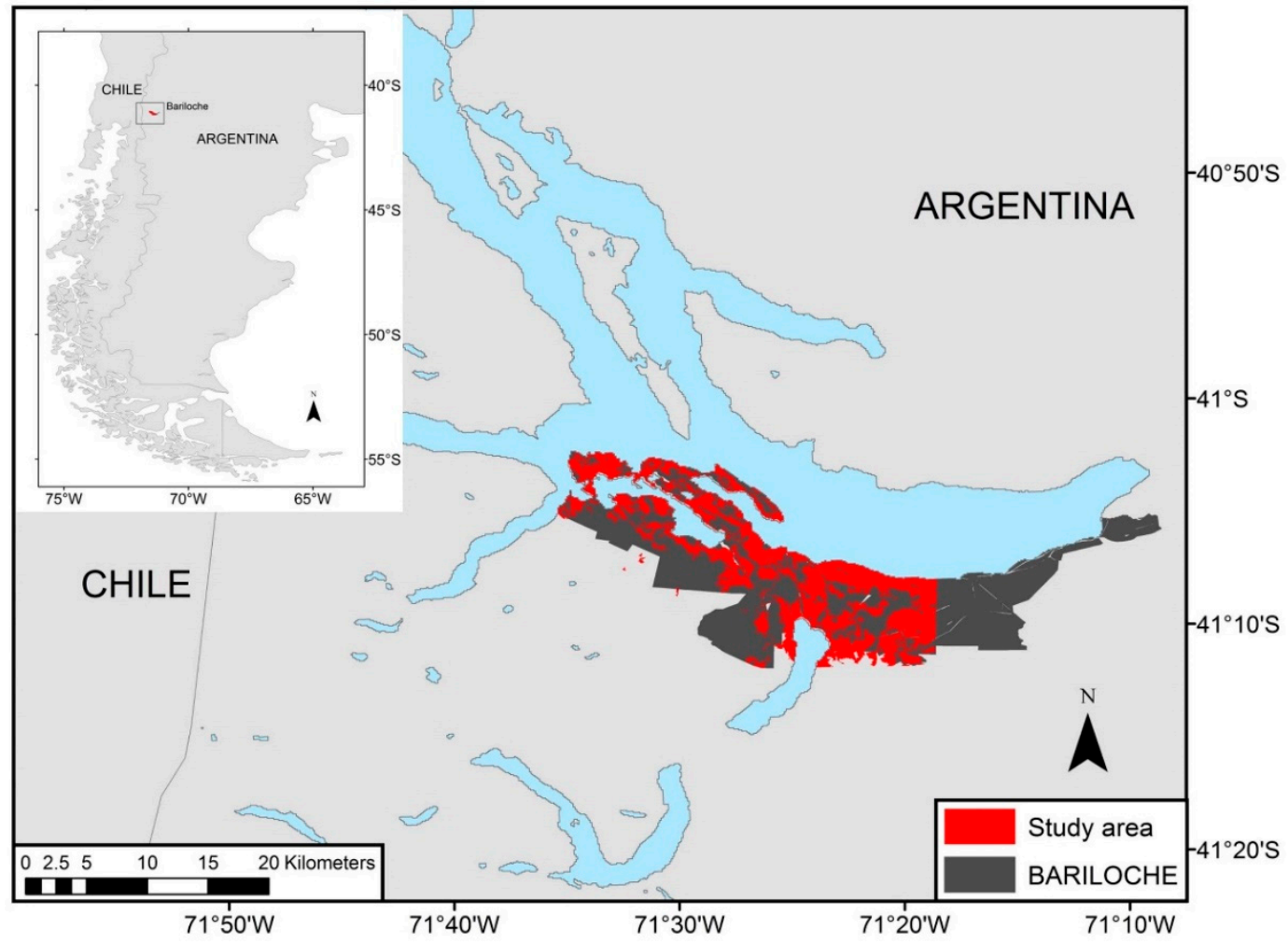

Figure 1. Study area: distribution of $A$. chilensis forests in San Carlos de Bariloche county.

\subsection{Austrocedrus Disease}

Data on the presence of $A$. chilensis disease were obtained from the database of the Forest Department of Río Negro Province, which includes requests to fell A. chilensis trees, between 2005 and 2016. A total of 2111 requests related to one or more cypress trees were located on the satellite image by using Google Earth (Google Earth Pro; http://www.earth.google.com, accessed September 2019). In order to filter out fell permits unrelated to the disease, we discarded those requests that related to new constructions which included felling healthy Austrocedrus trees. Using Google Earth's "Images history" tool, we eliminated felling records spatially and temporally (same year) associated with visible new constructions as well as those records where it was impossible to distinguish the presence of disease symptoms. Satellite imagery interpretation and data cleaning were performed visually by a human operator. The cleaning procedure resulted in 406 requests to fell trees reliably associated with symptoms of disease (ca. $20 \%$ ).

In order to strengthen the database, intensive field sampling was carried out, covering the study area. The sampling was organized in neighborhood transects along public roads, mostly perpendicular to the two principal avenues that run W-E from downtown Bariloche towards the western neighborhoods. The initial sampling point of each transect was the first street where A. chilensis trees were present, both on the sidewalk or inside the lots. The successive sampling points were located $50 \mathrm{~m}$ apart. Each transect was finalized $400 \mathrm{~m}$ away from the last urbanization, with the purpose of generating a suburban buffer. The transects covered a length of $71 \mathrm{~km}$ and 532 sampling points.

Each sampling point was georeferenced by a GPS Garmin, model GPS map 60, with 3-5 m accuracy and all the $A$. chilensis with DBH $>10 \mathrm{~cm}$ located in the visual field were recorded, including trees on the sidewalk as well as those inside the lots. The distance and direction to the georeferenced point were recorded, assessed by standardized steps and compass, respectively. Austrocedrus chilensis trees were visually characterized according to health condition, considering three categories: dead, diseased (i.e., trees with external symptoms such as chlorotic foliage, defoliation and/or with resin flux in the lower portion of the stem; just one symptom was considered enough for characterizing the tree as 
diseased [9]) and healthy (i.e., asymptomatic, no or very low crown transparency and green foliage). The Austrocedrus disease point database was set up both from the corrected fell requests coordinate and the field sampling (diseased and dead trees or group of trees) coordinates. This database included a total of 744 points.

Although in this study we only evaluated external symptoms of the disease, previous phytopathological studies which included Nahuel Huapi National Park and San Carlos de Bariloche found that the only biotic agent causing the massive mortality of $A$. chilensis forests in our study area is $P$. austrocedri $[9,10,28,39]$. The database of the Forestry Department of Río Negro Province does not include systematic records of trees' symptoms in relation to requests to fell $A$. chilensis trees; however, many records include observations about radical symptoms and necrotic tissues in the lower stem, information that is also mentioned in internal reports [40]. The only other biotic agent that was associated with massive mortality of $A$. chilensis trees, mainly in Chilean forests, is Cinara cupressi (Hemiptera: Aphididae), an introduced insect [41,42]. The Cinara attack is easily distinguishable by the presence of sooty mold (Capnodium spp.) in the affected trees. There is no record of mortality due to Cinara in the study area, and in the field sampling, sooty mold was not found. Thus, although no isolations of Phytophthora were performed in our study, it can be reliably assumed that the external symptoms considered are associated with Phytophthora.

\subsection{Anthropic and Environmental Properties}

Layers of climatic, topographical, hydrological and cadastral data were compiled in a geographic information system (GIS). The included variables were: distance to roads (m), distance to houses (m), mean annual precipitation $(\mathrm{mm})$, altitude (m. a.s.l.), slope $\left(^{\circ}\right)$, aspect $\left(^{\circ}\right)$ and distance to water courses $(\mathrm{m})$.

The annual precipitation layer was obtained by interpolation from digitized isohyets of the study area [43]. Layers of distances to water courses, distance to roads and distance to houses were generated through the QGis version 2.18.21 software [44] based on layers provided by the San Carlos de Bariloche Environment Department.

The altitude, slope and aspect were derived from a digital elevation model based on ASTER-GDEM images (Advanced Spaceborne Thermal Emission and Reflection Radiometer-Global Digital Elevation Model, Version 2, October 2011; Resolution $27 \times 27 \mathrm{~m}$ ). Because aspect is a circular variable, it was represented as both relative south aspect or degrees from the north (south) and relative east aspect or degrees from the west (east), following Anchorena and Cingolani [45]. South and east take values between $0^{\circ}$ and $180^{\circ}$; the higher value of the variable, the greater aspect towards this cardinal point. The decomposition of the circular variable "aspect" into the variables South and East has an ecological meaning in the Patagonian Andean Region. Degrees from north shows the maximum value $\left(180^{\circ}\right)$ in the quadrant with minimum solar irradiation (i.e., maximum soil moisture) in the southern hemisphere at mid latitudes. On the other hand, the orthogonal variable with maximum in the east (degrees from west) represents the effect of prevailing westerly wind circulation on soil moisture and plant moisture availability (leeward aspects have minimum desiccation by westerly winds and higher moisture than west facing windward aspects).

Both layers were generated through "Raster calculation" tool from QGIS software.

The site layers were converted to grids with $27 \times 27$ cells. All anthropic and environmental layers were masked with $A$. chilensis distribution area [46] in order to limit the analysis to the real forest distribution (Figure 1).

\subsection{Risk Model_Landscape Scale Study}

Based on the Austrocedrus disease point layer and on anthropic and environmental layers, a disease risk model was generated applying the maximum entropy algorithm [34] and the MaxEnt v.3.3.1 software. The Austrocedrus disease point database was converted to csv format and anthropic and environmental layers were converted to ascii format. The logistic output format was chosen, with values between 0 and 1, that indicates the probability of Austrocedrus disease occurrence. 
Ten split-sample model replicates were produced in order to obtain mean variability around mean values. In order to assess the model performance, $70 \%$ of the occurrence localities were randomly selected as the training set, while the remaining 30\% was reserved for testing and validating the resulting models. The area under the receiver operating characteristic curve (AUC) was calculated for each random set of assessment data, following Phillips et al. [34]. Variable importance was assessed using Jackknife tests, where each variable was successively removed while monitoring the loss of AUC compared to the complete model. In addition, univariate models were generated and AUC values were quantified.

In order to convert quantitative measures of disease risk (i.e., probability) to qualitative values (i.e., low, moderate or high risk), threshold values were selected. Thresholds were defined by maximizing agreement between the observed and modelled distributions for the sampled dataset. The threshold at which sensitivity (i.e., the proportion of true positive predictions to the number of actual positive sites) and specificity (i.e., the proportion of true negative predictions to the number of actual negative sites) were closest was adopted. This approach balances the cost arising from an incorrect prediction against the benefit gained from a correct prediction $[47,48]$. The lowest predicted value associated with any one of the observed presence records was also considered as a threshold (i.e., lowest presence threshold) [35]. This approach can be interpreted ecologically as identifying pixels predicted as being at least as suitable as those where the disease presence has been recorded. We defined three risk categories: low (with $p$ values lower than the lowest presence threshold); moderate ( $p$ values between the lowest and the sensitivity-specificity approach thresholds); and high risk ( $p$ values greater than the sensitivity-specificity approach threshold).

\subsection{Local Scale Study}

In each field sampling spot, in addition to categorizing the cypresses health condition, the distance to houses and to irrigated gardens were recorded. The A. chilensis health condition in each sampling point was classified into two categories: healthy and diseased, simplifying the categories generally used for describing $A$. chilensis forest health $[7,8,14]$. The healthy category included those sampling points that showed $100 \%$ of healthy trees. The diseased category included the sampling points where all the trees were diseased or dead, or when, even when there were asymptomatic plants, there was at least one symptomatic tree.

Since the study area corresponds to Mediterranean climate and summers are dry, the presence of gardens is always linked to artificial irrigation. There are no irrigation water flows in the city, but there are irrigation systems by hoses or sprinklers inside each property. The distance to houses and distance to irrigated gardens were classified in four categories: $<20 ; 20-50 ; 50-200$; and $>200 \mathrm{~m}$. Each sampled tree was also classified according to the distance to other diseased cypress tree, considering four categories: $<10 ; 10-20 ; 20-50$; and $>50 \mathrm{~m}$. Data from the local scale study were analyzed by Chi square analysis with the Infostat software.

\section{Results}

\subsection{Landscape Scale Study}

The Maxent algorithm allowed us to generate a risk model with a good predictive performance $($ AUC $=0.88 \pm 0.004)$. Variables related to anthropic structures, i.e., distance to houses and to roads, presented the greatest contribution in the risk model (Table 1), and thereby, these variables are strongly associated with the presence of Austrocedrus disease. The univariate models with higher predictive power were those that considered distance to houses and distance to roads, and the complete models that exclude these two variables were the ones with the most predictive power (Figure 2). 
Table 1. Relative contribution of the anthropic and environmental variables to the MaxEnt model. MAP: mean annual precipitation; South: relative south aspect; East: relative east aspect.

\begin{tabular}{cc}
\hline Variable & Percent Contribution \\
\hline Distance to houses & 41.6 \\
Distance to roads & 23.8 \\
Distance to watercourses & 12.5 \\
MAP & 7.4 \\
South & 5.8 \\
Altitude & 4.7 \\
Slope & 3.9 \\
East & 0.3 \\
\hline
\end{tabular}

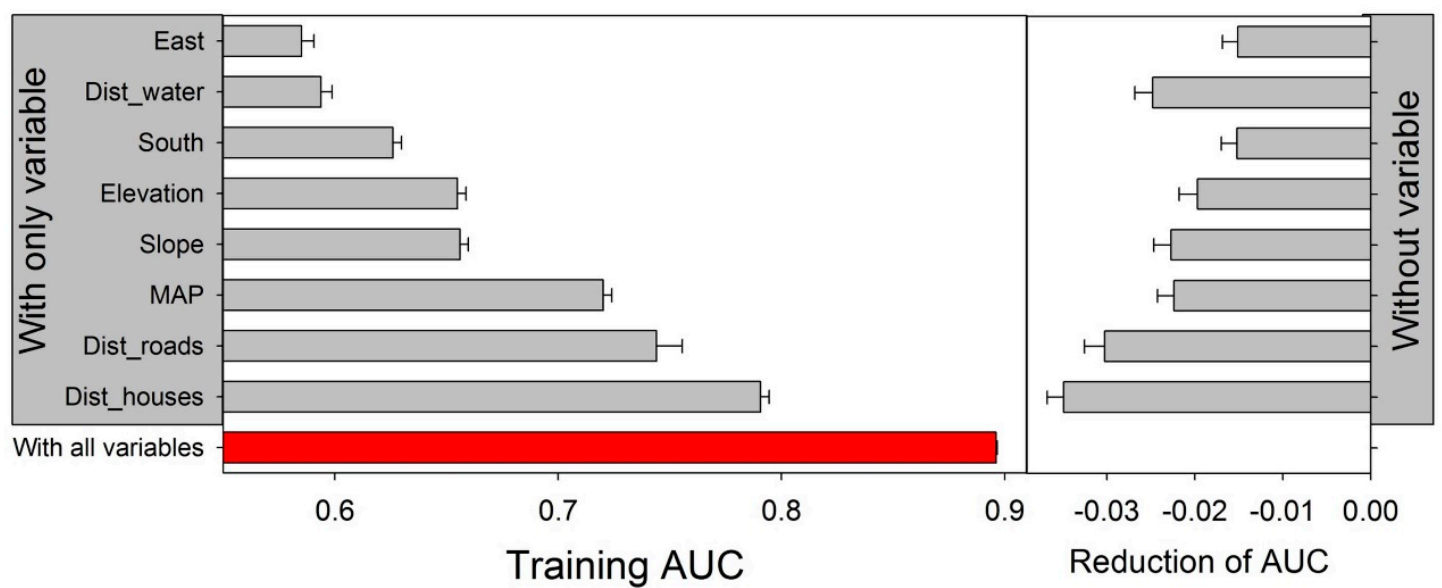

Figure 2. Area under the receiver operating characteristic curve (AUC) for the complete model (red bar) and for univariate models (bars on the left), and the reduction in AUC for the complete models excluding one variable (bars on the right). MAP: mean annual precipitation; South: relative south aspect; East: relative east aspect.

The probability of Austrocedrus disease occurrence exponentially decreased with increasing distance from houses (Figure $3 \mathrm{a}, \mathrm{c}$ ). At the same time, the risk abruptly falls as the distance from roads increases (Figure 3b,d). The cypresses located at the edge of the roads (from 1 to $100 \mathrm{~m}$ ), show a high risk of disease, while distances $>500 \mathrm{~m}$ showed a relatively much lower occurrence probability.

While the other environmental variables showed a lower contribution in the model (Table 1), some kept some association with Austrocedrus disease. The probability of disease occurrence decreased as the with distance to creeks, lake coastlines and watercourses (Figure $4 \mathrm{~b}$ ). On the other hand, the univariate models showed that mean annual precipitation (MAP) allows the generation of a moderately predictive risk [49], suggesting that MAP is associated with the disease occurrence (Figure 2). However, contrary to the pattern shown by Austrocedrus disease in natural environments [23], in the peri-urban studied area, the risk of diseasing decreases where precipitation increases (Figure 4a).

The risk of disease also tended to be higher in altitudes between 800 and $1000 \mathrm{~m}$. a.s.l. (Figure 4c), while the slope and the aspect, which in natural environments can be relevant factors $[23,24]$, in the studied area did not show a relationship with the risk level (Figure $4 \mathrm{~d}-\mathrm{f}$ ).

Figure 5a shows the modelled probability of Austrocedrus disease occurrence in the studied area. A strong spatial association of risk and urbanization intensity becomes evident when comparing disease risk probabilities with distance to houses (Figure 5b) and to roads (Figure 5c). In Figure 5b,c, the urban area (red hues), the peri-urban area (yellow hues) and still natural forests (green hues) can be distinguished. 

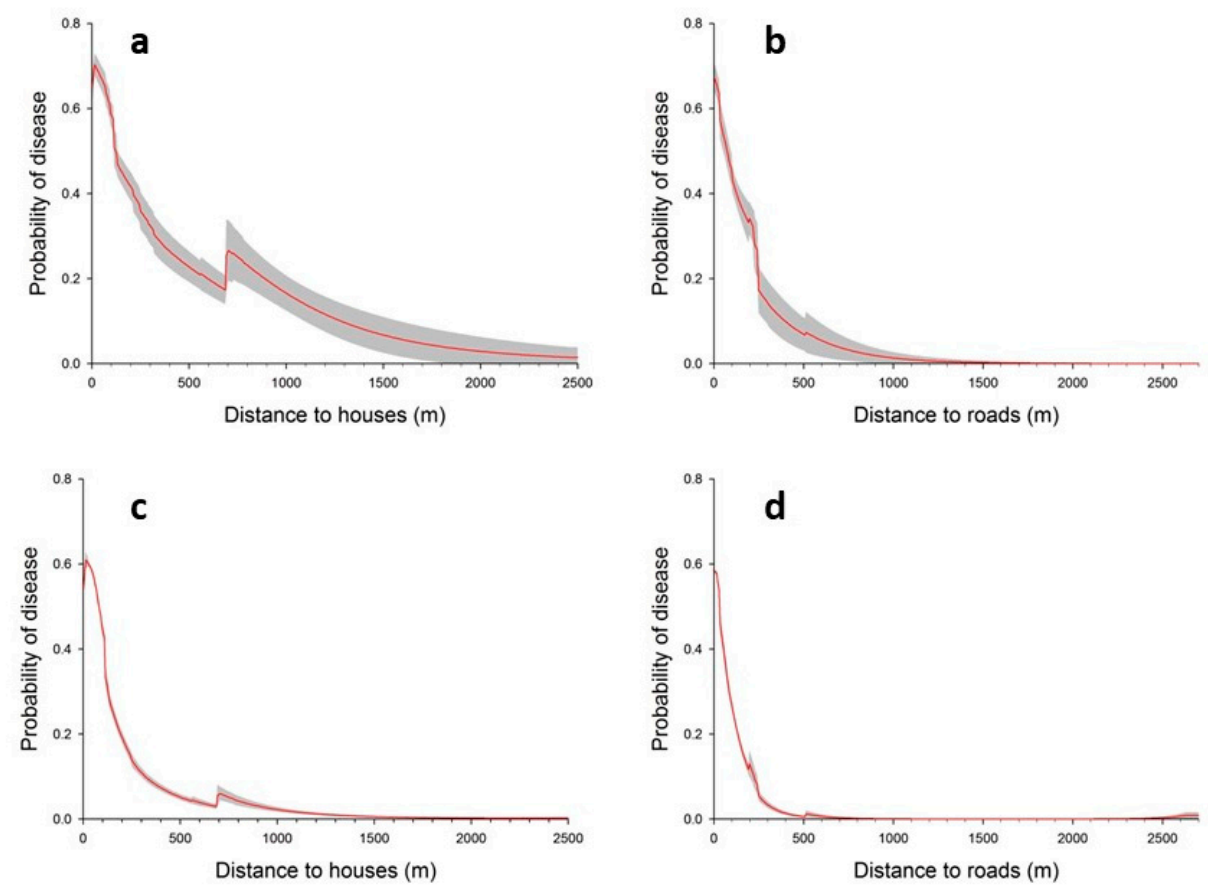

Figure 3. Austrocedrus disease risk according to MaxEnt algoritm in function of distance to houses $(\mathbf{a}, \mathbf{c})$ and distance to roads $(\mathbf{b}, \mathbf{d})$. Curves a and b show how the logistic prediction changes as each environmental variable is varied, keeping all other environmental variables at their average sample value; while curves $\mathrm{c}$ and d represent a Maxent model created using only the corresponding variable. Mean value \pm 1 standard deviation (gray area) is shown in each case.

a)

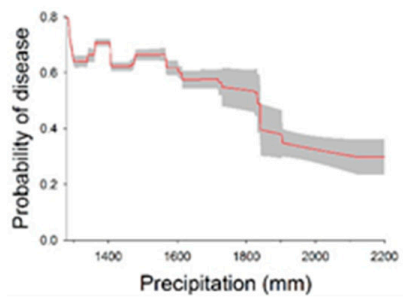

d)

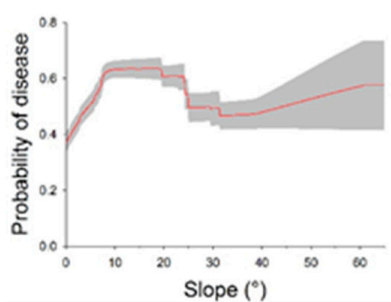

b)

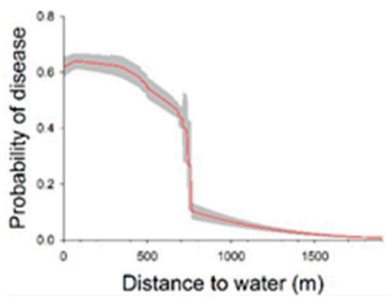

e)

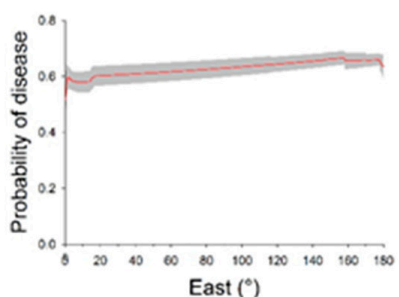

c)

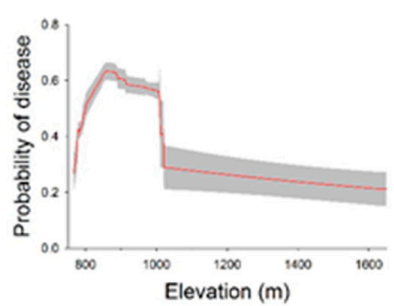

f)

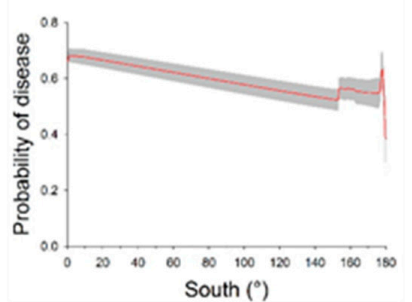

Figure 4. Austrocedrus disease risk according to MaxEnt algorithm in function of environmental variables. Mean value \pm 1 standard deviation (gray area) is shown. Environmental variables (axis $x$ ) include: mean annual precipitation (a), distance to water courses (b), elevation (c), slope (d), relative east aspect (e) and relative south aspect (f). 

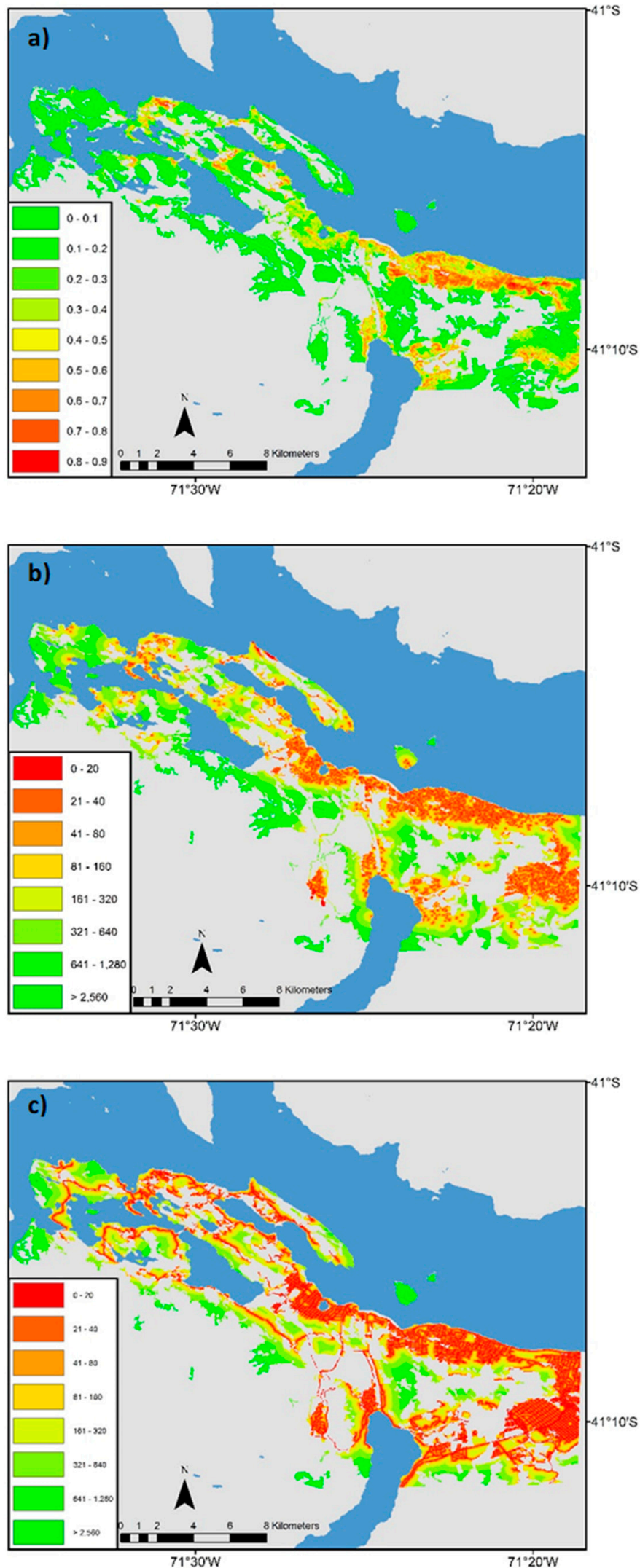

Figure 5. (a) Distribution of Austrocedrus disease risk according to MaxEnt model, (b) distance to houses $(\mathrm{m})$ and $(\mathrm{c})$ distance to roads $(\mathrm{m})$ in San Carlos de Bariloche county. 
Despite the fact that the disease has expanded considerably in the most urbanized areas, with medium and high risk of disease representing 60\% of the study area (1576 and 3368 ha, respectively), in $40 \%$ of the area the risk still remains low (Figure 6).

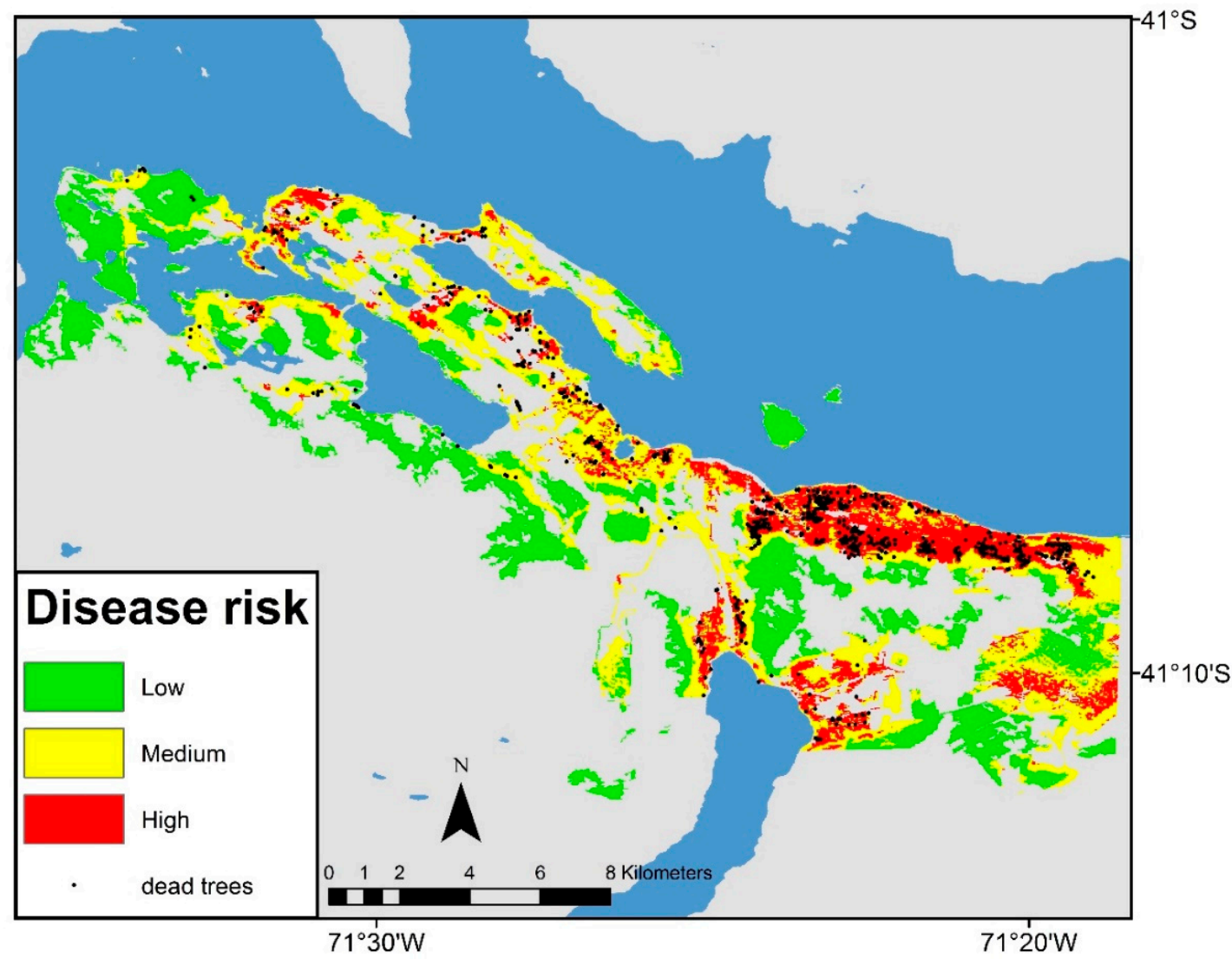

Figure 6. Distribution of Austrocedrus disease risk categories in San Carlos de Bariloche county. Black points correspond to the Austrocedrus disease occurrence layer used to generate the MaxEnt model.

\subsection{Local Scale Study}

In accordance with the landscape-scale study, local scale observations of the diseased trees or groups of trees were significantly associated with the distance to houses and to irrigated gardens. Specifically, frequency of points related to diseased trees or groups of trees tended to be associated at distances $<50 \mathrm{~m}$ from houses and irrigated gardens $\left(\chi^{2}=24.1, p<0.001 ; \chi^{2}=45.4, p<0.001\right.$, respectively). About $70 \%$ of the diseased trees were located less than $50 \mathrm{~m}$ from houses or irrigated gardens, while over the $50 \%$ of the asymptomatic trees (i.e., healthy) were located more than $200 \mathrm{~m}$ away from houses or irrigated gardens (Figure 7a). Clearly, other factors may be influencing disease occurrence, as $35 \%$ of the asymptomatic sampling points were located $<50 \mathrm{~m}$ from houses and gardens, and $22 \%$ of diseased trees were $>200 \mathrm{~m}$ away from those infrastructures (Figure $7 \mathrm{a}$ ).

Analyzing individual trees, it can be noticed that diseased trees are more frequently near to other affected trees, while the healthy trees tend to be far away from the diseased trees $\left(\chi^{2}=206.3, p<0.001\right)$ (Figure $7 b$ ). 


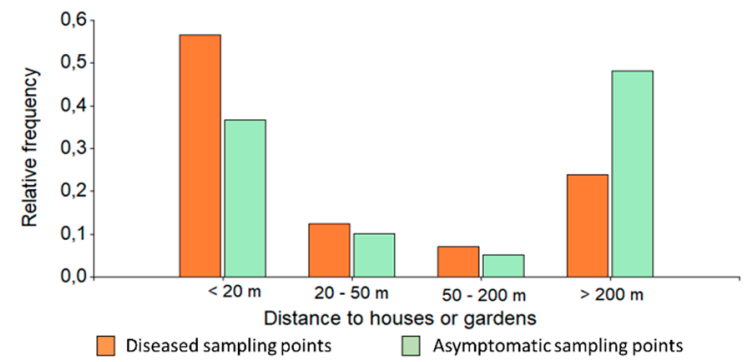

(a)

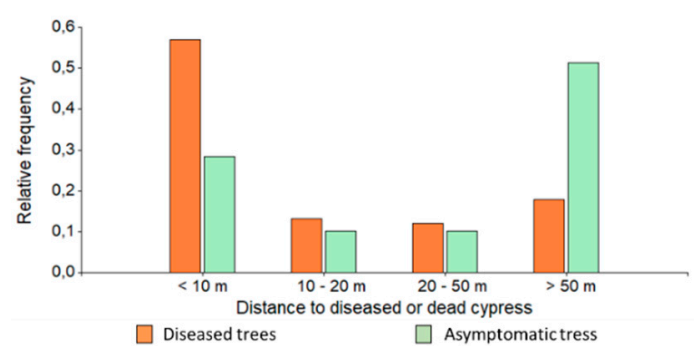

(b)

Figure 7. (a) Relative frequency of diseased and asymptomatic field sampling spots according to the distance to houses or irrigated gardens. (b) Relative frequency of diseased and asymptomatic field sampling trees according to the distance to a diseased or dead tree.

\section{Discussion}

Austrocedrus disease in the urban and peri-urban areas of San Carlos de Bariloche was shown to be associated with anthropic impacts: roads and houses, underscoring the role of human activities as enhancers of the disease. This result agrees with studies in natural areas which report that human activities are related with higher incidence and wider spread of Austrocedrus disease at the landscape scale [26,50], as well as with studies of other Phytophthora causing forest diseases [51,52]. Although very little is currently known about the natural dispersal mechanisms of $P$. austrocedri, natural spread is likely to occur via movement in water and soil, and possibly via animal and/or human activity [53].

The level of urbanization of forested areas was the main factor explaining Austrocedrus disease occurrence. Contrary to what was found in natural environments, in our study, the risk decreased with increasing rainfall and did not show a relationship with the slope nor aspect, which are relevant factors associated with the disease in natural areas [23,24], mediating soil moisture levels [54,55]. We propose here that the effect of urbanization overrides these natural factors by strongly modifying soil moisture regimes at a local scale around infrastructures. Artificial irrigation of gardens surrounding the houses and domestic septic tank drainage are likely candidates to create moisture conditions that favor the pathogen, independently of the slope, the aspect or the precipitation. Soil moisture enhances $P$. austrocedri infection, as it was proved not only in A. chilensis but also in a Juniperus forest from the United Kingdom affected by P. austrocedri [29]. The pathogen reproduces asexually, forming sporangia (spore sacs) in which the free-swimming zoospores develop and are released in water [53]. The ability to form asexual structures enhances the establishment of the pathogen [52]. On the other hand, P. austrocedri is homothallic (self-fertile) and forms abundant sexually produced oospores in colonies growing on V8 agar [9].

The negative association found between the disease and the mean annual precipitation could be an artifact related to the distribution of urbanization in the study area, which is mainly concentrated towards the drier eastern end. On the other hand, as precipitation increases to the west (Supplementary Material Figure S1e), soil depth, volcanic soils development and drainage improve, and therefore the impact of irrigation and other anthropic features that increase soil moisture might by reduced. In the opposite drier condition, even though rains diminish, apparently once the pathogen has invaded soils, anthropogenic structures artificially create the soil moisture conditions necessary for its development and infection of tree roots.

The local scale study shows that Austrocedrus disease is associated not only with nearness to houses and gardens, but also with the nearness to a diseased tree. These results suggest that diseased trees favor infection, since they implied the presence of Phytophthora inoculum. Where the inoculum is present and environmental conditions are proper for infection, the pathogen is able to invade and to kill the roots, and it can extend to the stem as long necrotic lesions in the inner bark. Necrosis initiates in the cambial zone and affects the entire thickness of the phloem and the last rings of the xylem $[15,56]$. Anthropogenic factors affecting soil moisture (irrigation, roads, drainage works) and dispersion (roads) 
favor the development of the disease when the inoculum is present. Phytophthora dispersion was associated with roads, where passers-by and vehicles transport the spores, as it occurs in natural areas, where cattle may also act as a vehicle for pathogen dispersion [50].

Permanent or temporary watercourses are also key for the dispersion of P. austrocedri [25,26], as occurs with other Phytophthora species around the world [27]. Although the distance to watercourses in the urban environment was not the most relevant feature, it showed an association with the risk of disease.

It is widely accepted that human activities act as a vector of dispersion of many invasive species, including pathogens [57]. Urban and peri-urban environments are the main ports of entry, mostly through the trade of nursery stock [58]. Dale et al. [59] found greater diversity of Phytophthora species in urban environments than in natural environments in British Columbia. Redondo et al. [52] found that the incidence of invasive Phytophthoras in urban areas (nurseries) is higher than in forests, and is also higher in rivers running through cities than through forests. However, there was a decrease in species richness from the most to the least anthropized environments (nurseries $>$ anthropogenic forests $>$ natural forests), showing there is an environmental filtering during the invasion process.

Cushman and Meentemeyer [51], in their study at the local, landscape and regional scales of the disease caused by P. ramorum, reported that human activity, along with temperature, moisture and host composition, is associated with increased prevalence of this pathogen. The authors found that forests on public land open to recreation exhibited a higher prevalence of disease than forests on private lands and that, at a regional scale, occurrence of the disease significantly increased as human population density increased in the surrounding area.

San Carlos de Bariloche constitutes a very particular case because this town is located in a natural forest within a protected natural area (Nahuel Huapi National Park). Many different land uses overlap in this area: urbanization (about 135,000 inhabitants), touristic and recreational use (about 800,000 tourists a year), cattle raising, and minor agricultural use. Large gardens with a variety of exotic ornamental species abound in the town, as well as numerous nurseries. As the town is located inside the forest, it is not only a port of entry of pathogens directly to the forest; it also represents a disturbance that can affect the natural development of the disease, its incidence and/or severity.

Several studies addressed the influence of human activities on the spread of Phytophthora species (e.g., $[30,51,58,59])$, but no or few studies have analyzed the effect of human activities on the incidence and severity of the diseases they cause once they are established in an area. The results found in this study show that, in peri-urban areas, the effect of anthropic factors exceeds the effect of environmental factors, and can even generate disease incidence, contrary to what would be expected according to predictive models based on environmental factors.

Landscape scale analyses were performed based on $27 \mathrm{~m} \times 27 \mathrm{~m}$-sized pixels, the minimal resolution of our topographic and vegetation databases. This implied that point data collected with ca. $5 \mathrm{~m}$ accuracy (trees, watercourses, houses, irrigated gardens) were assigned to larger, ca. $900 \mathrm{~m}^{2}$-sized pixels. Therefore, distance classes should be interpreted within certain margins (10s of meters) due to the blurring effect of rasterization. However, results from the local scale confirm the spatial relationships found at the landscape scale, thus providing confidence that neighborhood relationships hold true, irrespective of the scale analyzed.

The Austrocedrus disease risk model developed in this study is dynamic, which means that the risk of disease will change as the variables determining risk, especially the distance to houses and roads, change. Many areas in Bariloche county contain cypress forests with, currently, low risk of disease, but with potential for urbanization. Urbanization trends will likely further push the disease risk higher in these still forested peri-urban neighborhoods.

On the other hand, changes in working practices can greatly reduce the risk of spreading Phytophthora species. These changes are based on recognizing likely sources of contamination and routes through which contamination may be spread [60]. In the urban environment, it is practically impossible to apply closure measures or restrict transit, but taking into account the results found 
in our study, some plausible measures can be proposed. The risk map generated in this study can be a powerful tool for defining the preventive cutting of cypress trees at high risk of becoming diseased, considering both the risk model and the public risk that tree-falls could imply according to the location [61].

The relationship found between the disease and the distance to gardens demonstrates that irrigation artificially creates the soil moisture conditions necessary for the pathogen to develop and infect. In this sense, it is necessary to avoid creating favorable conditions for a moisture increase in soils where urbanization is advancing over A. chilensis forests, such as landscaping with irrigation, channelization, artificial water body creation or the diversion of streams. Since the relationship found between the disease risk and distance to houses might also reflect the effect of cesspools on soil moisture conditions, the investment in sewer networks can be proposed, in order to avoid ditching for black and gray waters drains in each property.

According to the model generated in our study, the distance to roads is also a key variable for defining disease risk. In this sense, reducing transit in forest areas at risk of disease during the wet seasons, when inocula are more abundant, can be a proper measure. Wet conditions tend to increase the movement of soil and debris and also provide better conditions for Phytophthora survival and infectivity, so the risk of effective transport is much higher under wet than dry conditions [60]. A technique that was recommended for reducing the spread of Phytophthoras is vehicle washing [60]. Vehicle washing is a proper management strategy for Phytophthora lateralis affecting Chamaecyparis lawsoniana forests in USA [62] and for Phytophthora cinnamomi, which causes a root disease of different forest and plant species in Australia [63]. Washing with water was shown to significantly reduce the amount of inoculum adhering to vehicles and boots [62]. Although it is difficult to apply these control measures in the urban environment, it would be plausible to install washing systems at the entrances to the undeveloped forests that surround the city, which are still at low risk of infection, according to the model. On the other hand, trail work activities, the opening of new roads across $A$. chilensis forests and new constructions in natural forest areas should take into account basic management practices in order to prevent Phytophthora dispersion. Basic measures that are widely recommended include minimizing the movement of soil, working from non-infested toward infested areas, avoiding working in high-risk areas under wet conditions and using clean or sanitized materials [60].

\section{Conclusions}

Anthropogenic factors influence the distribution of Austrocedrus disease in the urban and peri-urban environment. The distances to houses and to roads are the main variables determining the risk of forest to disease. Since human activities affect natural soil moisture (by irrigation, channelization, etc.), enhancing P. austrocedri infection, the effect of anthropogenic factors exceeds the effect of environmental factors, which were shown to be key in natural forests.

Since the risk model generated in this study is mainly supported by anthropogenic variables, highly dynamic in time and space, the risk level assignment of the model is also dynamic. Peri-urban forest areas considered today as at low risk of becoming diseased may change their level of risk as urbanization advances over them. Control measures, although difficult to implement in the urban environment, are necessary in order to protect this endemic forest species.

Supplementary Materials: The following are available online at http://www.mdpi.com/1999-4907/11/11/1183/s1, Figure S1: Environmental gradient in the study area. Figures show ranges of: (a) altitude (m. a.s.l.), (b) slope (\%), (c) relative east aspect $\left(^{\circ}\right)$, (d) relative south aspect $\left(^{\circ}\right)$ and (e) mean annual precipitation (m. a.s.l.).

Author Contributions: Conceptualization, T.K. and L.L.M.; Formal analysis, G.G. and T.K.; Methodology, G.G.; Software, T.K.; Supervision, L.L.M.; Writing—original draft, G.G. and L.L.M.; Writing-review and editing, T.K. and L.L.M. All authors have read and agreed to the published version of the manuscript.

Funding: This research received no external funding. 
Acknowledgments: We acknowledge G. Denham, M. Tarabini and F. Gomez for their technical support, and Fernando Salvaré for providing the database from the Forest Department of Río Negro Province. We acknowledge A Greslebin for her valuable contributions to the discussion.

Conflicts of Interest: The authors declare no conflict of interest.

\section{References}

1. Manion, P.D. Tree Disease Concepts, 2nd ed.; Prentice-Hall: Englewood Cliffs, NY, USA, 1991.

2. Ciesla, W.M.; Donaubauer, E. Decline and Dieback of Trees and Forests. A Global Overview; FAO: Rome, Italy, $1994 ;$ p. 90.

3. Waring, K.M.; O'Hara, K.L. Silvicultural strategies in forest ecosystems affected by introduced pests. For. Ecol. Manag. 2005, 209, 27-41. [CrossRef]

4. Del Campo, A.D.; Fernandes, T.J.; Molina, A.J. Hydrology-oriented (adaptive) silviculture in a semiarid pine plantation: How much can be modified the water cycle through forest management? Eur. J. For. Res. 2014, 133, 879-894. [CrossRef]

5. Recanatesi, F.; Giuliani, C.; Ripa, M.N. Monitoring Mediterranean Oak Decline in a Peri-Urban Protected Area Using the NDVI and Sentinel-2 Images: The Case Study of Castelporziano State Natural Reserve. Sustainability 2018, 10, 3308. [CrossRef]

6. Romagnoli, M.; Moroni, S.; Recanatesi, F.; Salvati, R.; Scarascia Mugnozza, G. Climate factors and oak decline based on tree-ring analysis. A case study of peri-urban forest in the Mediterranean area. Urban For. Urban Green. 2018, 34, 17-28. [CrossRef]

7. La Manna, L.; Rajchenberg, M. The decline of Austrocedrus chilensis forests in Patagonia, Argentina: Soil features as predisposing factors. For. Ecol. Manag. 2004, 190, 345-357. [CrossRef]

8. La Manna, L.; Rajchenberg, M. Soil properties and Austrocedrus chilensis decline in Central Patagonia, Argentina. Plant Soil. 2004, 263, 29-41. [CrossRef]

9. Greslebin, A.G.; Hansen, E.M. Pathogenicity of Phytophthora austrocedrae on Austrocedrus chilensis and its relation with "Mal del Ciprés" in Patagonia. Plant Pathol. 2010, 59, 604-612. [CrossRef]

10. Vélez, M.L.; Coetzee, M.P.A.; Wingfield, M.J.; Rajchenberg, M.; Greslebin, A.G. Evidence of low levels of genetic diversity for the Phytophthora austrocedrae population in Patagonia, Argentina. Plant Pathol. 2014, 63, 212-220. [CrossRef]

11. Taccari, L.E.; Greslebin, A.G.; Salgado Salomón, M.E.; Vélez, M.L. Two conifer species native to Patagonia threatened by Phytophthora austrocedri. For. Pathol. 2019, 49, e12496. [CrossRef]

12. Garbelotto, M.; Hayden, K.J. Sudden Oak Death: Interactions of the Exotic Oomycete Phytophthora ramorum with Naïve North American Hosts. Am. Soc. Microbiol. 2012, 11, 1313-1323. [CrossRef]

13. El Mujtar, V. Análisis Integrado de Factores Genéticos, Bióticos y Abióticos Para la Formulación de una Nueva Hipótesis Sobre la Etiología Del “Mal Del Ciprés”. Ph.D. Thesis, Universidad Nacional de la Plata, La Plata, Argentina, 2009.

14. Havrylenko, M.; Rosso, P.; Fontenla, S. Austrocedrus chilensis. Contribución al estudio de la mortalidad en Argentina. Bosque 1989, 10, 29-36. [CrossRef]

15. Vélez, M.L.; Silva, P.V.; Troncoso, O.A.; Greslebin, A.G. Alteration of physiological parameters of Austrocedrus chilensis by the pathogen Phytophthora austrocedrae. Plant Pathol. 2012, 61, 877-888. [CrossRef]

16. Troncoso, O.; Greslebin, A. Trabeculae in Patagonian mountain cypress (Austrocedrus chilensis) associated with Phytophthora austrocedri infection. IAWA J. 2018, 39, 209-220. [CrossRef]

17. Barroetaveña, C.; Rajchenberg, M. Hongos Aphyllophorales (Basidiomycetes) que causan pudriciones en Austrocedrus chilensis en pie. Bol. Soc. Arg. Bot. 1996, 31, 201-216.

18. Kitzberger, T. Ecotones as complex arenas of disturbance, climate, and human Impacts: The trans-Andean forest-steppe ecotone of Northern Patagonia. In Ecotones between Forest and Grassland; Myster, R., Ed.; Springer: New York, NY, USA, 2012.

19. Dondo Bühler, M.; de Torres Curth, M.; Garibaldi, L.A. Demography and socioeconomic vulnerability influence fire occurrence in Bariloche (Argentina). Landsc. Urb. Plann. 2013, 110, 64-73. [CrossRef]

20. Plaza, P.I.; Speziale, K.L.; Zamora-Nasca, L.B.; Lambertucci, S.A. Dogs and cats put wildlife at risk. J. Wildl. Manage. 2019, 83, 767-768. [CrossRef]

21. Ball, D.J.; Watt, J. The risk to the public of tree fall. J. Risk Res. 2013, 261, 1366-9877. [CrossRef] 
22. Bahamonde, H.; Peri, P.L.; Gargaglione, V.; Díaz, B.; Monelos, L.; Almonacid, L. Arbolado urbano en Patagonia sur. Principales Especies y su Manejo; Consejo Agrario Provincial: Río Gallegos, Argentina, 2018; p. 169.

23. Bacalá, N.B.; Rosso, P.H.; Havrylenko, M. Austrocedrus chilensis mortality in the Nahuel Huapí Park (Argentina). For. Ecol. Manag. 1998, 109, 261-269. [CrossRef]

24. La Manna, L.; Mateucci, S.D.; Kitzberger, T. Abiotic factors related to the incidence of Austrocedrus chilensis disease at a landscape scale. For. Ecol. Manag. 2008, 256, 1087-1095. [CrossRef]

25. La Manna, L.; Matteucci, S.D.; Kitzberger, T. Modelling potential Phytophthora disease risk in Austrocedrus chilensis forests of Patagonia. Eur. J. For. Res. 2012, 131, 323-337. [CrossRef]

26. La Manna, L.; Greslebin, A.; Matteucci, S.D. Avance de la mortalidad de los bosques de Austrocedrus chilensis a escala de paisaje. Rev. Asoc. Arg. Ecol. Paisaje 2014, 5, 17-24.

27. Erwin, D.; Ribeiro, O. Phytophthora Diseases Worldwide; APS Press: St Paul, MN, USA, 1996; p. 562.

28. Greslebin, A.G.; Hansen, E.M.; Sutton, W. Phytophthora austrocedrae sp. nov., a new species associated with Austrocedrus chilensis mortality in Patagonia (Argentina). Mycol. Res. 2007, 111, 308-316. [CrossRef]

29. Donald, F.; Green, S.; Searle, K.; Cunniffe, N.J.; Purse, B.V. Small scale variability in soil moisture drives infection of vulnerable juniper populations by invasive forest pathogen. For. Ecol. Manag. 2020, 473, 118324. [CrossRef]

30. Hansen, E.; Goheen, D.; Jules, E.; Ullian, B. Managing Port-Orford-Cedar and the Introduced Pathogen Phytophthora lateralis. Plant Dis. 1999, 84, 4-14. [CrossRef] [PubMed]

31. Meentemeyer, R.; Rizzo, D.; Mark, W.; Lotz, E. Mapping the risk of establishment and spread of sudden oak death in California. For. Ecol. Manag. 2004, 200, 195-214. [CrossRef]

32. Venette, R.C.; Cohen, S.D. Potential climatic suitability for establishment of Phytophthora ramorum within the contiguous United States. For. Ecol. Manag. 2006, 231, 18-26. [CrossRef]

33. Phillips, S.; Dudík, M. Modeling of species distribution wit Maxent: New extensions and comprehensive evaluation. Ecography 2008, 31, 161-175. [CrossRef]

34. Phillips, S.; Anderson, R.; Schapired, R. Maximum entropy modeling of species geographic distributions. Ecol. Model. 2006, 190, 231-259. [CrossRef]

35. Pearson, R.; Raxworthy, C.; Nakamura, M.; Townsend, P. Predicting species distributions from small numbers of occurrence records: A test case using cryptic geckos in Madagascar. J. Biogeogr. 2007, 34, 102-117. [CrossRef]

36. Dimitri, M. La Región de los Bosques Andino-Patagónicos II. Flora Dendrológica y Cultivada; Colección Científica del INTA: Buenos Aires, Argentina, 1982.

37. Dezzoti, A.; Sancholuz, L. Los bosques de Austrocedrus chilensis en Argentina: Ubicación, estructura y crecimiento. Bosque 1991, 12, 43-52. [CrossRef]

38. La Manna, L. Caracterización de los suelos bajo bosque de Austrocedrus chilensis a través de un gradiente climático y topográfico en Chubut, Argentina. Bosque 2005, 26, 137-153. [CrossRef]

39. Núñez, C.; Pérez, A.; Raponi, C. Maps of Austrocedrus chilensis forests affected by dieback. In Proceedings of the 7th Meeting of the International Union of Forest Research Organizations, IUFRO Working Party 7.02.09, Phytophthora in Forests \& Natural Ecosystems, Chubut, Argentina, 10-14 November 2014; p. 169.

40. Andean Forest Service. La problemática Sanitaria del Ciprés de la Cordillera en los Ecosistemas Urbanos de San Carlos de Bariloche; Secretaría de Producción, Dirección de Bosques, Servicio Forestal Andino: San Carlos de Bariloche, Argentina, 2012; p. 15.

41. Baldini, A.; Oltremari, J.; Holmgren, A. Efecto de Cinara cupressi (Hemiptera: Aphididae) sobre el ciprés de la cordillera (Austrocedrus chilensis) después de aplicar control químico. Cienc. Investig. Agrar. 2008, 35, 341-350. [CrossRef]

42. Peña, M.A.; Altmann, S.H. Reconocimiento del efecto de Cinara cupressi (Hemiptera: Aphididae) en el estado sanitario de Austrocedrus chilensis mediante imágenes multiespectrales. Bosque 2009, 30, 151-158. [CrossRef]

43. Barros, V.; Cordon, V.; Moyano, C.; Mendez, R.; Forquera, J.; Pizzio, O. Cartas de Precipitación de la Zona Oeste de las Provincias de Río Negro y Neuquén; Universidad Nacional del Comahue: Neuquén, Argentina, 1983 ; p. 66.

44. QGIS Development Team. QGIS Geographic Information System. Open Source Geospatial Foundation Project. 2018. Available online: http://qgis.osgeo.org (accessed on 21 September 2019).

45. Anchorena, J.; Cingolani, A. Identifying habitat types in a disturbed area of the forest-steppe ecotone of Patagonia. Plant Ecol. 2002, 158, 97-112. [CrossRef]

46. Servicio Forestal Andino de la Provincia de Río Negro. Mapa de Vegetación de la Provincia de Rio Negro; Consejo de Ecología y Medioambiente de la Provincia de Río Negro: San Carlos de Bariloche, Argentina, 2010. 
47. Manel, S.; Williams, H.C.; Ormerod, S.J. Evaluating presences absence models in ecology: The need to account for prevalence. J. Appl. Ecol. 2001, 38, 921-931. [CrossRef]

48. Liu, C.; Berry, P.; Dawson, T.; Pearson, R. Selecting thresholds of occurrence in the prediction of species distributions. Ecography 2005, 28, 385-393. [CrossRef]

49. Swets, J.A. Measuring the accuracy of diagnostic systems. Science 1988, 240, 1285-1293. [CrossRef]

50. La Manna, L.; Greslebin, A.; Matteucci, S.D. Applying Cost-distance analysis for forest disease risk mapping: Phytophthora austrocedrae as an example. Eur. J. For. Res. 2013, 132, 877-885. [CrossRef]

51. Cushman, J.H.; Meentemeyer, R.K. Multi-scale patterns of human activity and the incidence of an exotic forest pathogen. J. Ecol. 2008, 96, 766-776. [CrossRef]

52. Redondo, M.; Boerg, J.; Stenlid, J.; Oliva, J. Functional traits associated with the establishment of introduced Phytophthora spp. in Swedish forests. J. Appl. Ecol. 2018, 55, 1538-1552. [CrossRef]

53. CABI. Phytophthora austrocedri [original text by Green, S.]. In Invasive Species Compendium; CAB International: Wallingford, UK, 2020.

54. Colmet Dâage, F.; Lanciotti, M.; Marcolín, A. Importancia Forestal de los Suelos Volcánicos de la Patagonia Norte y Central; Instituto Nacional de Tecnología Agropecuaria: Bariloche, Argentina, 1995; p. 28.

55. La Manna, L.; Buduba, C.G.; Irisarri, J. Suelos volcánicos de la provincia del Chubut. In Suelos y Vulcanismo; Imbelloni, P., Barbosa, O., Eds.; Asociación Argentina de la Ciencia del Suelo: Buenos Aires, Argentina, 2020; pp. 333-360.

56. Troncoso, O. Histología de la afección de Phytophthora austrocedri en los tejidos de conducción de Austrocedrus chilensis. Ph.D. Thesis, Universidad Nacional de la Patagonia San Juan Bosco, Comodoro Rivadavia, Argentina, May 2018.

57. Mc Neely, J.A. The Great Reshuffling: Human Dimensions of Invasive Alien Species; The Word Conservation Union: Cape Town, South Africa, 2001; p. 242.

58. Liebhold, A.M.; Brockerhoff, E.G.; Garrett, L.J.; Parke, J.L.; Britton, K.O. Live plant imports: The major pathway for forest insect and pathogen invasions of the US. Front. Ecol. Environ. 2012, 10, 135-143. [CrossRef]

59. Dale, A.; Feau, N.; Ponchart, J.; Bilodeau, G.; Berube, J.; Hamelin, R.C. Urban activities influence on Phytophthora species diversity in British Columbia, Canada. In Proceedings of the Sudden Oak Death Sixth Science Symposium. Gen. Tech. Rep. GTR-PSW-255, San Francisco, CA, USA, 20-23 June 2016.

60. Swiecki, T.J.; Bernhardt, E. Best Management Practices for Preventing Phytophthora Introduction and Spread: Trail Work, Construction, Soil Import. 2018. Available online: http://phytosphere.com/publications/ Phytosphere_GGNPC_Soil_Phytophthora_BMPs_Jan2018.pdf (accessed on 21 October 2020).

61. Chauchard, L. Evaluación del Riesgo de Caída de Árboles en Áreas Recreativas. Región Patagonia; Administración de Parques Nacionales: Buenos Aires, Argentina, 2017; p. 80.

62. Goheen, D.J.; Mallams, K.; Betlejewski, F.; Hansen, E. Effectiveness of Vehicle Washing and Roadside Sanitation in Decreasing Spread Potential of Port-Orford-Cedar Root Disease. West. J. Appl. For. 2012, 27, 170-175. [CrossRef]

63. Colquhoun, I.J.; Hardy, G.E. Managing the risks of Phytophthora root and collar rot during bauxite mining in the Eucalyptus marginata (Jarrah) forest of Western Australia. Plant Dis. 2000, 84, 116-127. [CrossRef]

Publisher's Note: MDPI stays neutral with regard to jurisdictional claims in published maps and institutional affiliations.

(C) 2020 by the authors. Licensee MDPI, Basel, Switzerland. This article is an open access article distributed under the terms and conditions of the Creative Commons Attribution (CC BY) license (http://creativecommons.org/licenses/by/4.0/). 